\title{
AZ ISMERŐSI, BARÁTI KAPCSOLATHÁLÓZATOK SZEREPE A 65 ÉV FELETTIEK ÖNKÉNTESSÉ VÁLÁSÁBAN
}

María Celeste Dávila (2017): The relationship between social networks and volunteerism among seniors. Journal of Social Service Reserach, 44(1) pp. 38-49.

\section{DOl: https://doi.org/10.53585/OnkSzem.2022.1.123-127}

Az elmúlt tíz-tizenöt évben jelentősen megszaporodott azon kutatásoknak a száma, amelyek azt vizsgálják, hogy mely tényezők befolyásolják a 65 év felettiek önkéntessé válását. Az eredmények egyik csoportja szerint az önkéntesség erősen kötődik az életciklus egyes szakaszaihoz. Így például a társadalmi - érzelmi szelektivitás elmélete ${ }^{2}$ szerint az életciklus előrehaladtával bizonyos, érzelmileg jelentős életcélok (például társas kapcsolatok) kapnak prioritást.

A motivációs kutatások pedig azt mutatják, hogy az idősek önkéntes motivációjában - a fiatalokénál jelentősebb - szerepet játszik a társadalmi elvárásoknak való megfelelés, illetve a társas kapcsolatok megtartásának igénye.

Más tanulmányok a hatékony toborzási módszerek felől közelítik az időskorúak önkéntessé válását. Általános tétel, hogy az egyik legjobb toborzási módszer a szájpropaganda (word of mouth), amikor az egyik önkéntes hozza magával a másik önkéntest. Különösen érvényes ez az időskorúakra, akik kevésbé fogékonyak a formális toborzási módszerekre. Ugyanakkor az is igaz, hogy az informális toborzási módszerek csak azok esetében hatékonyak, akiknek széles társadalmi hálózataik és aktív személyes kapcsolataik vannak.

\footnotetext{
1 Bartal Anna Mária (PhD) szociálpolitikus-szociológus, az Önkéntes Szemle föszerkesztője

${ }^{2}$ Carstensen, Lara (2006): The influense of a sense of time on human development. Scince, 30., pp. 1913-1915.
} 
Egyrészt ezek az eredmények szolgáltak kiinduló pontul María Celeste Dávila a madridi Complutense Egyetem ${ }^{3}$ szociálpszichológia professzora tanulmányának, amelyben az önkéntesség és a társas hálózatok közötti kapcsolatot vizsgálta. Másrészt pedig az a tény, hogy Spanyolországban nem csak az önkéntesség népességen belüli aránya alacsony (12-13 százalék) ${ }^{4}$, hanem a 65 év felettiek között is. A 2013-as SHARE ${ }^{5}$ felmérés szerint a 65 év feletti spanyolok mindössze 4,2 százaléka nyilatkozott úgy, hogy végzett önkéntes vagy jótékonysági munkát.

\section{A TÁRSADALMI HÁLÓZATOK}

A tanulmány elméleti megalapozását a társadalmi hálózatok elemzése adta, amelyeknek Dávila három - egymást átfedő - funkcióját emeli ki, mint amelyek az önkéntességben is szerepet játszhatnak. Egyrészt a társadalmi hálózatok olyan kapcsolatokat hoznak létre, amelyek a viselkedések széles körét befolyásolják (például az étkezési szokásoktól kezdve, a dohányzásról való leszokáson át az együttmúködésig, illetve az olyan támogató magatartásformákig, mint az önkéntesség vagy a jótékonyság). Másrészt a hálózatokon keresztül információkat, támogatásokat lehet megosztani. Ezek olyan interakciókra utalnak, mint az egyének, a csoportok, a közösségek között kialakuló kapcsolatok és a kölcsönhatások. Harmadrészt pedig a társadalmi hálózatok a normakövetés eszközei is lehetnek. Az ilyen az esetekben az önkéntességet folytató emberek azt közvetítik, hogy ezen tevékenységek normatívak és társadalmilag hasznosak.

A szerző kiemeli, hogy az életciklussal nem csak a társadalmi hálózatok szerkezete változhat, hanem ezek mélysége is. Időskorban a közeli kapcsolatok állandósulnak és viszonylag stabilak maradnak (ezzel együtt be is szűkülhetnek), míg a perifériás kapcsolatok csökkenek. Az időskorúak személyes szociális hálózataiban felértékelődnek azok a kapcsolatok, amelyek szoros érzelmi töltettel és támogatáscserével járnak.

\footnotetext{
${ }^{3}$ Spanyolország legrégebbi, és jelenleg Európa harmadik legnagyobb egyeteme.

${ }^{4}$ Összehasonlításul érdemes megjegyezni, hogy 2017-ben az Európai Értékrend Kutatás szerint Magyarországon az önkéntes szervezetek tagsági aránya 35 százalék volt.

${ }^{5}$ SHARE - Survey of Helath, Ageing and Retirement in Europe http://www.share-project.org/home0.html
} 


\section{A TÁRSADALMI HÁLÓZATOK ÉS AZ ÖNKÉNTESSÉG KÖZÖTTI KAPCSOLATOK FELTÁRÁSÁRA ALKALMAZOTT KUTATÁSMÓDSZERTAN}

A tanulmány kutatásmódszertanilag két vizsgálat, egy statisztikai másodelemzés és egy személyes megkérdezésen alapuló kérdőíves felmérés alapján igyekezett feltárni a társadalmi hálózatok és az önkéntesség közötti kapcsolatot. A statisztikai másodelemzés alapját a SHARE által gyűjtött adatok képezték, amelyek lehetővé tették, hogy a spanyolországi időskorú népesség reprezentatív mintáján vizsgálják meg a személyes szociális háló méretét, a hálózaton belüli interakciókat és az azokkal való elégedettséget, valamint az önkéntes és/vagy jótékonysági munkában való részvételt. A kérdőíves vizsgálat célja az volt, hogy részletesebben feltárják a társadalmi hálózatok szerepét az időskorú önkéntesek toborzásában. Ennek érdekében a spanyol időskorúak legnagyobb szövetségének ${ }^{6} 152$ önkéntesét kérdezték meg kérdőíves felvétel formájában leginkább arról, hogy: vannak-e és hányan önkéntesek rokonaik, barátaik körében; ki javasolta a számukra, hogy önkéntesnek jelentkezzenek, és azzal milyen kapcsolatban álltak, illetve javasolta-e már az önkéntességet másoknak is, és azok kik voltak, milyen kapcsolatban állt velük.

\section{AZ ÖNKÉNTESSÉG TÁGÍTJA ÉS MÉLYÍTI A SZOCIÁLIS HÁLÓZATOT}

A statisztikai másodelemzés eredményei szerint a spanyol időskorúak szociális hálózatának mérete igen alacsony volt és többségüknél főként közeli rokonokból állt. Azonban, ahogy a kapcsolatok száma nőtt, úgy csökkent a családi kapcsolatok jelentősége és tágult ki egyéb ismerősök felé. A vizsgálat fontos eredménye volt, hogy szignifikáns különbségek mutatkoztak az önkéntesek és nem önkéntesek szociális hálózatában, ugyanis az önkéntes munkát végzők szociális hálójának átlagos mérete nagyobb volt. De nem csak a szociális háló mérete mutatkozott nagyobbnak az önkéntesek körében, hanem a bizalmasok közelsége is alacsonyabb volt. Ez azt jelentette, hogy az önkéntesek több olyan bizalmas személyt tudtak megnevezni, akik földrajzilag is távolabb éltek tőlük, míg a nem önkéntesek általában egy-két földrajzilag közelálló bizalmast tudtak csak nevesíteni. További két figyelemre méltó

\footnotetext{
${ }^{6}$ Ez az UDP nevű szövetség, az Union Democratica de Pensionistas y Jubilados de España volt, amelyet 1976-ban alapítottak, és több mint 3000 regionális, tartományi, területi és ágazati egyesület alkotja.
} 
eredménye volt a másodelemzésnek. Egyfelől, az önkéntes munka végzése szempontjából a kapcsolatok mennyisége az igazán fontos, míg az azzal való elégedettség és az interakciók szintje kevésbé mutatkozott meghatározónak. Másfelől, ahogy növekszik a kapcsolatok száma, úgy nő annak az esélye, hogy valaki interakcióba lép egy másik, olyan személlyel, aki önkéntes munkát végez.

\section{HATÉKONY TOBORZÁSI STRATÉGIA: ELŐSZÖR KAPCSOLATOK, UTÁNA JÖN AZ ÖNKÉNTESSÉG IS}

A két kutatási felvétel eredményei alapján a szerző arra a következtetésre jutott, hogy Spanyolországban azért alacsony az idősek körében az önkéntesség, mert társadalmi hálózataik kicsik és főként rokonokból áll. A homogén társadalmi hálózattal rendelkezőket kisebb valószínúséggel kérik fel, vagy hívják önkéntesnek, míg a szélesebb, barátokból, ismerősökből is álló szociális hálózat növeli az önkéntesség valószínűségét.

A tanulmány egyik fő értéke, hogy Davíla fontos javaslatokat fogalmazott meg a gyakorlati szakemberek számára is, az időskorú önkéntesek toborzását illetően. Amennyiben növelni szeretnénk az időskorúak önkéntes tevékenységben való részvételét, az egyik potenciálisan hatékony stratégia lehet, hogy ösztönözni és lehetővé kell tenni, hogy az idősek a szűk szociális hálózatukon kívüli személyekkel is találkozzanak. Azaz, bővítsék és diverzifikálják társas kapcsolataikat, például az olyan, időseknek szervezett programok, mint a kirándulások, múzeumlátogatások, tanfolyamok által, amelyek elősegíthetik új emberekkel való kapcsolatok felvételét is. Az új ismeretségek, barátságok növelhetik az önkéntessé válás esélyeit is.

A kutatás eredményei is alátámasztották a szájpropagandán alapuló toborzási stratégiákban a szociális hálózatok hasznosságát. Ehhez azonban az kell, hogy a toborzást végzők a barátok, ismerősök köréből kerüljenek ki, és inkább legyenek azonos nemúek, mivel azok befolyása nagyobbnak mutatkozott a célzott vizsgálatok alapján, mint az ellentétes neműeké.

\section{AZ ÖNKÉNTESSÉG ELŐNYEI AZ IDŐSEK SZÁMÁRA}

Számos kutatás igazolta az önkéntesség hozzájárulását az idősek jóllétéhez, mentális egészségének megőrzéséhez. Az idősebb korú önkéntesek nem egyszerűen növelhetik az önkéntesek számát, hanem „új stílust” is adhatnak az önkéntességnek a bennük meglévő lojalitással, toleranciával és türelemmel. Csökkenthetik az idősekkel szembeni előítéleteket, 
és növelhetik az esélyét a különböző generációs találkozásoknak, együttműködéseknek. Ehhez azonban világosan kell látni, hogy az időskorú önkéntesek nem alkotnak homogén csoportot. Egyre több az olyan nyugdíjas, aki magasabb iskolai végzettséggel, több pénzügyi forrással, valamint magasabb szintű technológiai műveltséggel és használattal éri meg az időskort. Ezért az időskorúak önkéntestoborzási stratégiájának is új módszereket kell alkalmazni az új kihívásokhoz. 